\title{
A thematic approach to the research agenda for regional and local government
}

Mark Callanan and John Loughlin

\section{The background}

Before the 1980s, academic research on subnational government in Western states concentrated primarily on local government in the context of fairly stable national welfare regimes. In this context, local authorities acted as 'agents' of central governments in the delivery of policy programmes which were mostly designed by the centre (Darby et al. 2002). Local governments in most of these states were assigned specific tasks such as transport and housing related to their own localities. They also provided an important dimension of democratic representation through local elections. The degree of political, fiscal and policy autonomy varied across the different states as did the situation of local authorities in federal versus unitary states (Loughlin 2004; Loughlin et al. 2010).

From the early 1980s, two developments changed this situation of top-down approaches to subnational government. First, there was the inauguration of a new phase of globalization following the collapse of the Bretton Woods system of exchange, the two oil crises in the 1970s, and the crisis of the Keynesian economic model as well as of the welfare state (Held et al. 2009). This meant a shift in the role of the state which moved from greater intervention in society and the economy to a more hands-off approach, that is, a shift from Keynesianism to neoliberalism (Jessop 1990). Henceforth, the market would be favoured over the state in policy approaches. Some scholars would argue that this phase of globalization was a de facto propagation of neoliberalism across the globe (Held et al. 2009; Harvey 2005). The role of international financial institutions such as the International Monetary Fund (IMF) and the 
World Bank (WB) but especially the IMF also changed from what had been a combination of Keynesian and economic liberal approaches decided in the 1950s at Bretton Woods to one which was about the implementation of the neoliberal model or what became known as the 'Washington Consensus' (Stiglitz 2002: 195-213). Traditionally, from the rise of the nation-state throughout the nineteenth century, economic activities had been based on national economics and economics as a discipline dealt largely with such national activities. It is true that there was a growing internationalization of trade and commerce from the nineteenth century but this was dominated by Western powers such as Britain with its vast trading empire. After 1980 and the growth of the neoliberal paradigm, however, there developed new forms of global economic and financial activities that largely escaped the control of national governments (Held et al. 2009). Banks especially engaged in initiatives which involved the creation of new financial instruments which few understood. This was at the root of the subprime mortgage crisis which would break out in 2007-08 (Watson 2011: 455).

Second, in western Europe, European integration was relaunched in the 1980s, partly in response to the wider changes in the global economy and partly because of a new generation of leaders such as the French president Valéry Giscard d'Estaing and the German chancellor Helmut Schmidt. As European integration intensified, the role of subnational government began to change. The European Community, in the mid-1980s, developed for the first time a specifically European regional policy and provided (relatively modest) funding which incentivized European regions and other local authorities to mobilize in order to obtain European grants. In effect, a new emerging system of European governance led to a reconfiguration of the governments of the European Union (EU) member states and their relations with both the EU institutions, especially the European Commission which encouraged these developments, and the subnational authorities. This has been termed 'multi-level governance' (Hooghe and Marks 2001; Bache and Flinders 2015). At the same time, most European states either strengthened their existing regions or invented new ones at least as units of administration. The notion of a 'Europe of the Regions' became part of the fads and fashions of territorial government reforms (Loughlin 1996; Elias 2008; Abels and Battke 2019). At the same time, local authorities also received a boost through instruments such as the Council of Europe's Charter of Local Self-Government, promulgated in 1988, which strengthened the autonomy of local authorities vis-à-vis not just central governments but also regional governments.

The regional and local authority mobilization of the 1980s and early 1990s which accompanied these developments sought to increase subnational rep- 
resentation in the EU and resulted in the creation in 1994 of the Committee of the Regions (CoR), which was a great disappointment to many European regionalists who sought something like a 'Third Tier' of EU governance along the lines of the German Bundesrat (Warleigh 1997). Nevertheless, the establishment of the CoR is important because, for the first time, subnational authorities had some representation at the level of EU policymaking and its importance has continued to grow (Piattoni 2019: 16-32). This European-wide mobilization had an important impact on the way in which territorial governance was perceived both in member states and in those states who wished to join the EU. The general trend in European states was for the creation of new, or the strengthening of existing, levels of meso-government. Federal countries had their own 'ready-made' regional tiers of government, but regionalization processes became more pronounced in countries traditionally designated as unitary states. French regions became central actors in a new French planning system (Loughlin 2007). The United Kingdom (UK) launched an ambitious devolution programme. The Nordic states of Sweden and Finland experimented with regional administrations as did countries such as Ireland and Greece. The then candidate states of central and eastern Europe (rather reluctantly ${ }^{1}$ ) set up regional administrations. Some of these measures were ways by which the European Commission could influence territorial governance as they often insisted on these levels as conditions for obtaining EU funding. But once an institution is created it often develops a life and momentum of its own (as can be seen in the case of the CoR). The Council of Europe also encouraged these moves as ways of consolidating subnational democracy after decades of communist centralization.

More broadly, some would argue that the late 1990s until 2008 were a period of global economic growth (Held et al. 2009). It was also a period when western states, perhaps buoyed by surplus revenues, engaged in political, policy and fiscal decentralization and began to loosen fiscal restraints (Loughlin and Martin 2005). Local authorities were given greater leeway to borrow funds on the open markets to finance ambitious policy programmes which were less constrained by central governments. This was true both within the EU and for other states such as Canada and the United States (US). In the US, fiscal federalism was an expression of the same general tendency. A further development closely linked to globalization was the suggested rise in importance of 'urban growth centres', as engines of economic growth and enterprise clusters. The fact that cities act as transport, communications and third-level educational hubs for their wider regional hinterland, have a distinct cultural heritage, involve the concentration of skilled employees, and engender networks between businesses, had led to an increased international interest in new arrangements to reflect the governance of city-regions or metropolitan areas. Sasken (2001) and 
others have developed the notion of the 'global city'. Originally, this referred to a small group of cities (New York, London and Tokyo) who were thought to be at the top of a pyramidal hierarchy. Later, however, this was expanded to include a much greater group of cities. Castells (2003) argues that functions incorporated in global cities exist through a network of cities spanning the globe. We could develop a hypothesis that growing economic prosperity provides one of the conditions for decentralization and greater regional and local autonomy.

\section{The 2008-10 financial and economic crisis}

Beginning in the US with the subprime borrowing crisis, the new global financial system began to unravel and to have serious impacts on the economies of western states. Carlo Monticelli, Vice Governor of the Council of Europe Development Bank, expressed it thus: 'The world as we know it has come to an end: a new unsettled order prevails in global economic and financial affairs ... [T] he transformation had fundamental causes: the financial turmoil that erupted in 2008 cannot be blamed or praised as the origin of the new order' (Monticelli 2019: 1, italics in text). Monticelli goes on to argue that there are elements of both continuity and fundamental change in the transition to the new global economic and financial order. Elements of continuity include: 'the persistence of the US dollar as the pivot currency of the international system; the endurance of the international standards regime in financial regulation; and the survival of the orthodox approach to macroeconomic policies outlined in the "Augmented Washington Consensus"” (ibid.: 2). However, fundamental change has also occurred mainly related to the challenge to US hegemony from the emerging economies led by China. Most strikingly, according to Monticelli, the G20 has replaced the G7 as 'the key decision-making forum on global economic and financial matters' (ibid.: 3). Some of the key features of the new order include: fragmentation of many aspects of global governance but also purposeful experimentation in reforming; dissatisfaction with global governance as it had existed under the old G7 hegemony and an attempt to create greater inclusiveness with the creation of the G20. What have emerged are not really adequate reforms of the G7 system but new tensions between the US, on the one hand, and Russia and China on the other. The election of Donald Trump and, in the UK, Brexit, both expressions of a new populism, have exacerbated these tensions.

National governments struggled to respond to the crisis and fought to maintain the stability of their financial systems by bailing out major banks who 
were deeply affected by the crisis. In the EU, Greece almost went bankrupt and had to be bailed out by the European Central Bank. Ireland, Italy and Spain soon followed Greece on this path. The benign expansion of the 1990s and early 2000s definitely ground to a halt. Although the worst case scenarios - the collapse of central banks and of the Euro - did not materialize, the context in which governments, whether national or subnational, operated changed significantly. National governments sought to rein in public spending through austerity programmes and tightened control over the fiscal actions of subnational governments. There was a considerable degree of recentralization reversing decades of decentralization. The EU has struggled to maintain its cohesion and legitimacy as its member states were divided on the path out of the crisis. France and Germany wished to maintain ever closer integration and even push towards a deeper federal Europe while the new states from eastern and central Europe and peripheral states such as Greece and Ireland became less ardently pro-European. The most dramatic event was Brexit as the UK voted in a referendum to quit the EU altogether. Behind this decision was a populist movement led by Nigel Farage and his UKIP party but this was a sentiment found among much wider swathes of the British population. Brexit has placed a large question mark not just over the UK's relationship with the EU but the UK's very future as a union, especially given the difficulties posed by the Irish border question and the rise of Scottish nationalism. Populism has grown right across Europe and represents a challenge to the 'mid-century consensus' between the centre-right and the centre-left which has dominated European politics for decades. In the US, similar developments underlie the success of Donald Trump in winning the presidency.

\section{The global financial and economic crisis as a watershed for regional and local government? Some preliminary observations}

In the 1990s and 2000s, a series of comparative analyses of subnational government had identified a fairly consistent set of themes in the reform of subnational government across different jurisdictions (see for example Loughlin et al. 2010; Dollery et al. 2008; Denters and Rose 2005; Kersting and Vetter 2003; John 2001; Norton 1994; Hesse and Sharpe 1991). Among other issues these included territorial restructuring, both functional and financial forms of decentralization, managing intergovernmental relations across different territorial levels, reforming executive models (including the introduction of directly elected mayors), managerial reforms (broadly inspired by $\mathrm{New}$ 
Public Management (NPM)-type ideas), and continued experimentation with a variety of mechanisms designed to facilitate greater citizen participation. In this section we make some preliminary observations on trends in these areas, and whether these trends were disrupted by the financial crisis leading to radical changes in direction, or indeed whether changes since 2008 mark a continuation of pathways that were established before the crisis. We also link this discussion to the different chapters of the book that follow this introductory chapter.

To what extent was the financial crisis a watershed moment in terms of regional and local autonomy? Some recent research may allow us to make some preliminary comments. A 2017 Organisation for Economic Co-operation and Development (OECD) review of trends in multi-level governance suggested that most OECD countries had embarked on different forms of regionalization and decentralization reforms up until the financial crisis. While the financial crisis may have postponed (or even reversed) this trend in some countries, there has been renewed interest in such reforms in many OECD countries, and in some instances the crisis strengthened incentives for reform, albeit in the context of reduced financial flexibility (OECD 2017). Thus it could be suggested that the financial crisis has prompted a new wave of decentralization to local and regional levels, albeit in a context of diminished resources and austerity policies (Pike et al. 2017).

Nicolas Keuffer and Andreas Ladner in Chapter 2 review the development of various indexes measuring decentralization and local and regional autonomy, the comparisons that can be drawn based on these, and what these indexes suggest around trends in regional and local autonomy over time. They find some evidence for continuity in patterns of local and regional autonomy, even allowing for some disruption or disturbance resulting from the global financial crisis, but that the effect of the crisis on subnational autonomy largely concerned the financial dimensions of autonomy.

One theme that has manifested itself in subnational reform in several countries at different intervals is territorial restructuring, which has often involved the merger or amalgamation of subnational authorities to create larger territorial units, sometimes referred to as territorial upscaling (Baldersheim and Rose 2010; Steiner et al. 2016). Askim et al. (2017) identify a number of potential drivers for territorial reforms, including fiscal stress, urbanization, and decentralization of functions to the subnational level. While fiscal stress certainly accentuated following the financial crash in 2008, one could associate the other factors with more incremental change. In terms of actual territorial reforms that have been implemented, we can observe a varied pattern across countries 
- there are certainly examples of countries increasing the size of their local government units through mergers, amalgamations and in some cases the abolition of particular subnational tiers (both before and after the financial crisis). In some instances the reforms were prompted by the financial crisis but in others they reflected the continuation of structural reform trends already well established in advance of the crisis (Ladner 2017). Equally there are also examples of countries that have reduced the size of their local authorities through secessions, and others again where the size of subnational units has not changed at all over an extended period of time. An alternative or complement to territorial reform has been the growing use of cooperative arrangements between subnational authorities to pool resources, variously referred to as inter-municipal cooperation, trans-scaling, or shared services (Hulst and van Montfort 2007; Baldersheim and Rose 2010; Bouckaert and Kuhlmann 2016).

In Chapter 3, Pawel Swianiewicz discusses the long-standing debate over territorial reform and restructuring at local level, including both amalgamations and secessions. There is a particular focus here on reviewing reforms during the first two decades of the twenty-first century, and comparing reasons for territorial reform initiatives both before and after the global financial crisis, with some evidence to suggest that cost savings and economies of scale took on a greater prominence in the rationale behind amalgamation reforms undertaken after 2008 .

The themes of devolution and decentralization are particularly salient in the context of researching trends in regional and local government. As noted above, the period of global growth from the 1990s until the global financial crisis is sometimes associated with greater devolution of responsibilities to the subnational level. In terms of financial issues and financial decentralization, one might intuitively have expected the global financial crisis to have had significant effects, at least over the short term. Repercussions on the revenue side included reduced intergovernmental transfers and grant income, as well as reduced income in core revenue sources such as property tax, leading to increased debt levels. In some instances specific subnational taxes were abolished entirely, or regional and local authorities incurred losses in financial investments. On the expenditure side, there was an increased emphasis on cutback management, on prudent financial management, and dealing with greater expenditure demands in social services (Perlman 2009; Ter-Minassian and Fedelino 2011; Martin et al. 2012). Whether these are short-term trends or whether they prove to have more lasting or transformational effects remains a somewhat open question (Martin et al. 2012; Ammons et al. 2012). Certainly in some countries, the financial crisis prompted governments to postpone introducing reform plans for subnational financing, while in other cases the 
financial crisis provided a window of opportunity to introduce new revenue sources for subnational authorities or to reform existing revenue sources. In addition, the crisis also prompted some subnational authorities to work together to establish joint vehicles to allow authorities to improve their access to external financing, including through raising bonds on financial markets (OECD 2017).

In Chapter 4, Romain Pasquier argues that although the global financial crisis produced some recentralization, particularly in financial terms, the effects of globalization and European integration, and the increased focus on the territorial dimension of economic development (and the economic dynamism of several regions and cities) has prompted greater devolution and resulted in new territorial political opportunities. Different forms of regionalization are observed, as well as differences in the political capacity of regions, suggesting the influence of possible mediating factors, such as state traditions, national policy styles and intergovernmental relations, institutional and economic resources, political leadership, and territorial political cultures and identities, which can either facilitate or impede the approach taken by subnational actors.

Long-term trends such as globalization, greater capital and labour mobility, and more intense international competition have also been linked with increased interest in the concept of 'city regions' or metropolitan governance, given the importance of cities as hubs of economic, social, educational, environmental and cultural assets, drawing on ideas around economic concentration and agglomeration economies based on both new economic geography and urban economics (Scott 2001; Pike et al. 2017). The terms city-region and metropolitan governance have become part of the popular and political discourse around subnational reform, to the extent that they have become contested and subject to competing definitions (Rodríguez-Pose 2008; Janssen-Jansen and Hutton 2011). However, there is general consensus around the use of the terms in capturing the wider functional urban area of a core city as well as its suburban and rural hinterland, which typically span several traditional municipal boundaries. There seems to be a paradox here between the growing acceptance of the key role metropolitan areas play in a globalized economy, on the one hand, and the relative weakness of metropolitan governance structures (where they exist) on the other. One suggestion is that metropolitan governance is likely to take the form of network governance, relying on mechanisms based on coordination, collaboration, consensus-building and facilitation (Neuman and Hull 2009; Janssen-Jansen and Hutton 2011). Operational manifestations include structured but essentially voluntary forms of municipal cooperation to address city-region issues that span both the urban core and the suburban hinterland, as well as more formalized structural arrangements such as met- 
ropolitan councils or metropolitan mayors (OECD 2017). We could therefore see metropolitan governance as primarily being a response to longer-term trends in globalization - that said, there are also some examples of countries introducing metropolitan structures as a response to the financial crisis (see for example Longo and Mobilio 2016).

In Chapter 5, Niamh Moore-Cherry, Andy Pike and John Tomaney discuss the growing attention given by both academics and policymakers to the governance of city-regions and metropolitan areas. The authors identify a number of salient themes within this field, including the relationship between core cities and their wider regional hinterland, institutional and governance arrangements and collaboration in metropolitan areas, city-regions beyond the developed countries, and the prospect of developments in this area exacerbating existing economic, social and spatial inequalities between city-regions and 'left behind' areas.

In Chapter 6, Sami Moisio and Andrew Jonas deliberate over concepts of city-regions and city-regionalism and the blurring of boundaries between government, business, the economy and civil society, linking this trend to economic globalization, neoliberalism and the advocacy role of international organizations. Domestic or internal influences are also apparent, including the state's role in activating growth coalitions, and the discourse, framing and 'imaginaries' of debates over city-regionalism. They point to the dominant economic narrative associated with metropolitan strategies and city-regions as knowledge-intensive centres of innovation and units of global competition and investment, and the need to balance these with social, political, spatial and environmental considerations.

There are also some suggestions that the financial crisis led to a deterioration in intergovernmental relations, given that the crisis was accompanied by reduced financial intergovernmental grant transfers, and in some cases an increase in devolved responsibilities (Perlman and Benton 2012). Longer-term comparative reviews of intergovernmental relations tend to suggest a blend of continuity and path dependency, on the one hand, as well as subtle changes introduced through the influence of international trends such as NPM reforms and regionalization (including in unitary states) on the other (Goldsmith and Page 2010).

A variety of frameworks on themes such as globalization and multi-level governance point to the increased mutual interdependency between different levels of governance in the contemporary world. Global institutions like the United Nations (UN), G8, IMF, WB, World Health Organization (WHO), 
World Trade Organization (WTO) and OECD have become increasingly influential in specific fields with a strong transnational dimension, such as climate change, development aid, health pandemics or trade liberalization. In addition, a series of regional groupings of states have been established, of which the most developed and influential has been the EU. As Pike et al. (2017) observe, state power has dispersed both upwards to supranational bodies with regulatory functions such as the IMF, WB, WTO, EU, the North American Free Trade Agreement (NAFTA), the Association of Southeast Asian Nations (ASEAN) and Mercosur, downwards to regional and local levels, and sideways to trans-territorial networks.

The above-mentioned multi-level governance evolved through the study of the EU's regional policy, where EU arrangements for drawing down structural and cohesion funds required national governments to establish mechanisms for involving regional and local governments in determining where EU money would be spent in their territory, and in the monitoring of that spending. These arrangements opened up new arenas for direct dialogue between supranational, national, regional and local actors.

Achieving public policy goals can often involve concerted action at various levels of governance. In policy areas with a strong transnational dimension, frameworks frequently encompass actors at various levels from the global to the local. Taking the example of climate change mitigation and adaptation, UN-led commitments to reducing greenhouse gas emissions are translated into EU legislative commitments, which in turn feed into national policy and legislative frameworks. This in turn drives concrete actions that are often regional or local in nature in terms of making the transition to a low carbon economy (through, for example, addressing energy consumption, spatial planning considerations and dealing with the consequences of climate change). These trends have been exacerbated by the two parallel processes of firstly devolution to the subnational level, and secondly the increased influence of supranational institutions, of which the EU is the most advanced as a multi-level political system (Jensen et al. 2014).

In Chapter 7, Mark Callanan and Michaël Tatham discuss trends and developments in the impact the EU has had on regional and local governments, and in the way subnational actors have responded to Europeanization. Some nuances are observed concerning the period after the global financial crisis. For example, the authors note that there has been less use of 'hard' regulation but a greater range of 'soft' policy instruments, including some that encroach on areas traditionally outside the EU's formal competences. 
Recent years have also seen a growing prominence for managerial reforms. In addition to the territorial consolidation and rescaling mentioned above, this has included reorganizing service delivery (including opting for private and non-profit providers through privatization, contracting out and competitive tendering), subnational agencification and corporatization through publicly owned entities or companies, streamlining service delivery processes, introducing performance measurement initiatives and new budgeting and accounting systems, and modernizing services through greater use of technology (Schwab et al. 2017; Steen et al. 2017). The financial crisis and the cutback and austerity policies that followed it did certainly induce the introduction of radical cost saving initiatives such as budget controls and reducing staffing levels in certain countries, but arguably had less influence on more transformational types of reform such as managerial delegation (Perlman and Benton 2012; Ladner 2017). As with public service reform initiatives at the national level, different countries have approached these kinds of reforms in different ways, with varied experiences between states and varied experiences between subnational authorities within states, with reform effects often mediated by domestic traditions and legacies. Many subnational authorities have therefore taken an evolutionary rather than a revolutionary approach (Bouckaert and Kuhlmann 2016; Ammons et al. 2012). It is also possible to discern a shift towards some initiatives that can be characterized as post-NPM reforms (Christensen and Lægreid 2008; Osborne 2006). Rather than seeking to sweep away NPM entirely, post-NPM is usually seen as a means to address some of the shortcomings of earlier NPM reforms - examples include bringing selected services that were contracted out back into direct 'in-house' provision by subnational authorities, and greater efforts at coordination and joined-up government to address fragmentation (Bouckaert and Kuhlmann 2016; Schwab et al. 2017; Steen et al. 2017).

In Chapter 8, Sabine Kuhlmann examines trends in managerial reforms, with a particular focus on the local level in the UK, Sweden and Germany, each of course being reflective of different state traditions. The chapter compares developments in externalizing local service delivery, through privatization, outsourcing, agencification but also selected recent trends towards insourcing and 're-municipalization', as well as internal managerial reforms and in particular performance measurement and benchmarking. Some evidence of convergence is apparent, but equally differences remain around several nuances, such as whether reforms are imposed from below or originate within local governments themselves.

Another reform theme has been around efforts to develop a more participatory form of governance, supplementing traditional institutions of representative 
democracy at regional and local level with the establishment of new avenues engaging citizens in more inclusive decision-making processes, involving a wider range of governmental and non-governmental stakeholders (see for example John 2001; Denters and Rose 2005; Denters 2017). As Blair (1991) notes, participative reforms are not an entirely new phenomenon, and can be traced back to initiatives since the 1970s. However, the declining trust in political institutions, often cited as a rationale for these reforms, has become more manifest as a result of the financial crisis, growing transnationalization and the increased complexity of governance (Denters 2017). Recent years have seen growing variety and intensity within this area of reform. Among a wide range of examples we may include traditional public meetings and consultation procedures, satisfaction surveys and opinion polls, interactive websites and online discussion fora, focus groups and citizens' panels, age-specific councils, petition rights, referendums, cooption onto committee structures, community forums, town meetings, participatory budgeting, and planning cells and citizens' juries. Some mechanisms place the emphasis on gathering feedback on citizens' views on decisions to be made or their experiences as users of a particular service, perhaps drawing on a cross-section of a large number of people in the area. Others tend to place more emphasis on the deliberative tradition, particularly around complex issues, which might imply a more ongoing relationship between local government and stakeholder groups. Research has suggested that greater citizen engagement has become more routinized, and while it might have been expected to have suffered during the global financial crisis, the use of such mechanisms has largely survived this period (Godwin 2014), and if anything may have become more pronounced. Indeed some research has associated the use of more participative mechanisms with a greater propensity to pursue more radical (and conflictual) cost-cutting strategies during the financial crisis (Jimenez 2014). Much of the research thus far has tended to focus on the extent of public participation through such mechanisms, what can facilitate and hamper citizen involvement, and how representative public participation is of the wider population - however, there is less emphasis on the perhaps more challenging task of identifying the impact of such approaches on decision-making.

In Chapter 9, Frank Hendriks and Ank Michels survey the evolution of new forms of citizen involvement in local and regional decision-making, including both direct plebiscitary mechanisms (such as referendums and internet-based platforms), as well as participatory and deliberative mechanisms (such as citizens' juries, neighbourhood councils and age-related forums), suggesting that there has been a steady increase in the use of a variety of different initiatives over time, and that this trend is likely to continue into the future. 
As noted above, one suggested effect of the global financial crisis after 2008 was the rise in populist movements in different parts of the world. New movements and parties sometimes including 'maverick' candidates emerged which were initially dismissed by the traditional political establishment, even though many of these went on to find themselves in elected office, not just at national level, but also at regional and local level.

In Chapter 10, Silvia Bolgherini and Davide Vampa trace the evolution of populist movements and the challenges these pose to traditional political competition at regional and local levels. Initially focused on the 'radical right' challengers to establishment parties, the growth of populist movements has also extended to left-wing, regionalist and countervailing 'state nationalist' populist movements. They also observe the emergence of local and regional civic movements and non-party candidates emphasizing direct links between voters and representatives as a challenge to traditional party-based organization. As many of these 'anti-elitist' movements have found themselves in government in regional and local executives, this may pose questions as to what extent these movements gradually become part of the 'establishment'.

Some time ago, Peter John (2001) identified a link between growing complexity and fragmentation, on the one hand, and demands for clearer leadership at subnational level on the other. The suggestion was that complexity and fragmentation at subnational level have arisen from a variety of factors - including many of those reflected above, such as new territorial arrangements at local, metropolitan and regional level, multi-level governance, increased contracting out and use of private and voluntary organizations to deliver services, agencification of services, and new participative arrangements. Addressing fragmentation and greater efforts at coordination has sometimes been associated with post-NPM trends or 'new public governance' (Christensen and Lægreid 2008; Osborne 2006). And it can reasonably be argued that if anything complexity and fragmentation are likely to remain key challenges into the future. This changed environment has often been accompanied by calls for more clearly defined leadership arrangements and clearer lines of accountability. This has been most obviously manifested through the more widespread introduction of directly elected mayors in several jurisdictions, the rationale for which typically includes enhancing democratic accountability and legitimacy, and giving local and metropolitan areas in particular a more identifiable and visible leader. However directly elected mayors are by no means universal, and strengthening local leadership could also be said to be reflected in other models of executive decision-making at subnational level, such as cabinet-based structures, or the council-manager model (Heinelt et al. 2018; Carr 2015; Garrard 2007; Mouritzen and Svara 2002; Berg and Rao 2002; Klausen and Magnier 1998). 
In the final Chapter, Niels Karsten, David Sweeting, Ulrik Kjær and Simona Kukovič assess different dimensions of leadership at subnational level. They review various typologies and indexes of executive leadership that have been developed, and find evidence of continuing trends towards both a personalization of leadership selection and greater concentration of local executive powers, most obviously (though not exclusively) manifested through the proliferation of directly elected mayors at both municipal and metropolitan level.

The chapters that follow in this book address these issues in greater detail. In contrast to conventional comparative reviews based on chapters addressing individual countries, this book presents a more thematic analysis. The authors of individual chapters, each leading scholars in their field, address particular themes in a comparative perspective. In particular, authors discuss whether there have been changes in trends in their area when comparing the pre-2008 era and the post-2008 era following the global financial crisis. The general conclusion that emerges on a perusal of these contributions is that the 2008 crisis has had some impact on territorial governance especially on fiscal issues but that there is greater continuity than radical change. Sometimes territorial processes and reforms that were in place before the crisis have continued but what has changed is the context in which they occur. What is striking is the extent to which territorial governance systems are characterized by hybridity. For example, NPM reforms co-exist with traditional public administration systems: the former has not replaced the latter but has modified its practice.

The authors drafted their chapters shortly after the outbreak of the Covid-19 pandemic in 2020. While at this stage it was far too early to be drawing robust academic conclusions on the implications of this latest crisis for regional and local government, each of the authors briefly reflect on whether there may be any potential lessons from the fallout from the post-2008 crisis that may have applicability following the Covid-19 pandemic and the post-2020 era. Given the emphasis in the Elgar Research Agenda series on exploratory research and looking ahead to the future research agenda, the authors also devote attention to identifying promising avenues for future research in their area.

Undoubtedly, there is room for further research in a number of areas which we may simply enumerate as follows:

- Territorial entities and globalization;

- Multi-level governance and the EU;

- Hybrid public management systems;

- The changing role of cities and the creation of city-regions;

- New forms of regional and local participation; 
- The territorial dimension of the 'new populism';

- The impact of Covid-19 on territorial governance.

\section{Notes}

1. There were fears that decentralization measures would undermine the sovereignty of the national governments which had just liberated themselves from Soviet domination.

\section{References}

Abels, G. and Battke, J. (2019) 'Regional Governance in the EU or: What Happened to the "Europe of the Regions"', in G. Abels and J. Battke (eds), Regional Governance in the EU: Regions and the Future of Europe. Cheltenham, UK and Northampton, MA, USA: Edward Elgar Publishing, pp. 1-14.

Ammons, D.N., Smith, K.W. and Stenberg, C.W. (2012) 'The Future of Local Government: Will Current Stresses Bring Major, Permanent Changes?', State and Local Government Review, 44(1), 64-75.

Askim, J., Klausen, J.E., Vabo, S.I. and Bjurstrøm, B. (2017) 'Territorial Upscaling of Local Governments: A Variable-Oriented Approach to Explaining Variance amongst Western European Countries', Local Government Studies, 43(4), 555-576.

Bache, I. and Flinders, M. (eds) (2015) Multi-Level Governance: Essential Readings. Cheltenham, UK and Northampton, MA, USA: Edward Elgar Publishing.

Baldersheim, H. and Rose, L.E. (2010) 'A Comparative Analysis of Territorial Choice in Europe: Conclusions', in H. Baldersheim and L.E. Rose (eds), Territorial Choice: The Politics of Boundaries and Borders. Basingstoke: Palgrave Macmillan, pp. 234-259.

Berg, R. and Rao, N. (eds) (2005) Transforming Local Political Leadership. Basingstoke: Palgrave Macmillan.

Blair, P. (1991) 'Trends in Local Autonomy and Democracy: Reflections from a European Perspective', in R. Batley and G. Stoker (eds), Local Government in Europe: Trends and Developments. Basingstoke: Palgrave Macmillan, pp. 41-57.

Bouckaert, G. and Kuhlmann, S. (2016) 'Introduction: Comparing Local Public Sector Reforms - Institutional Policies in Context', in S. Kuhlmann and G. Bouckaert (eds), Local Public Sector Reforms in Times of Crisis: National Trajectories and International Comparisons. Basingstoke: Palgrave Macmillan, pp. 1-20.

Carr, J.B. (2015) 'What Have We Learned about the Performance of Council-Manager Government? A Review and Synthesis of the Research', Public Administration Review, 75(5), 673-689.

Castells, M. (2003) 'Global Informational Capitalism', in D. Held and A. McGrew (eds), The Global Transformations Reader. Cambridge: Polity, pp. 311-334.

Christensen, T. and Lægreid, P. (2008) 'NPM and Beyond: Structure, Culture and Demography', International Review of Administrative Sciences, 74(1), 7-23. 
Darby, J., Muscatelli, A. and Roy, G. (2002) 'Fiscal Federalism and Fiscal Autonomy: Lessons for the UK from Other Industrialised Countries', University of Glasgow, accessed 14 February 2021 at https://strathprints.strath.ac.uk/6921/6/ strathprints006921.pdf.

Denters, B. (2017) 'Participation and Democratic Accountability: Making a Difference for the Citizens', in C. Schwab, G. Bouckaert and S. Kuhlmann (eds), The Future of Local Government in Europe: Lessons from Research and Practice in 31 Countries. Baden-Baden: Nomos Verlagsgesellschaft, pp. 79-99.

Denters, B. and Rose, L.E. (eds) (2005) Comparing Local Governance: Trends and Developments. Basingstoke: Palgrave Macmillan.

Dollar, D. and Kraay, A. (2004) 'Growth Is Good for the Poor', in F. Lechner and J. Boli (eds), The Globalization Reader. Oxford: Blackwell, 2nd edition.

Dollery, B.E., Garcea, J. and LeSage, E.C. (eds) (2008) Local Government Reform: A Comparative Analysis of Advanced Anglo-American Countries. Cheltenham, UK and Northampton, MA, USA: Edward Elgar Publishing.

Elias, A. (2008) 'Introduction: Whatever Happened to the Europe of the Regions? Revisiting the Regional Dimension of European Politics', Regional \& Federal Studies, 18(5), 483-492.

Garrard, J. (ed.) (2007) Heads of the Local State: Mayors, Provosts and Burgomasters since 1800. Aldershot: Ashgate.

Godwin, M.L. (2014) 'Civic Engagement and Fiscal Stress in American Cities: Insights from the Great Recession', State and Local Government Review, 46(4), 249-259.

Goldsmith, M.J. and Page, E.C. (eds) (2010) Changing Government Relations in Europe: From Localism to Intergovernmentalism. London: Routledge.

Harvey, D. (2005) A Brief History of Neo-Liberalism. Oxford: Oxford University Press.

Heinelt, H., Magnier, A., Cabria, M. and Reynaert, H. (eds) (2018) Political Leaders and Changing Local Democracy: The European Mayor. Basingstoke: Palgrave Macmillan.

Held, D., McGrew, A.G., Goldblatt, D. and Perraton, J. (2009) Global Transformations: Politics, Economics and Culture. Cambridge: Polity Press, 2nd revised edition.

Hesse, J.J. and Sharpe, L.J. (1991) 'Local Government in International Perspective: Some Comparative Observations', in J.J. Hesse (ed.), Local Government and Urban Affairs in International Perspective. Baden-Baden: Nomos Verlagsgesellschaft, pp. 603-621.

Hooghe, L. and Marks, G. (2001) Multi-Level Governance and European Integration. Lanham, MD: Rowman \& Littlefield.

Hulst, R. and van Montfort, A. (eds) (2007) Inter-Municipal Co-operation in Europe. Dordrecht: Springer.

Janssen-Jansen, L.B. and Hutton, T.A. (2011) 'Rethinking the Metropolis: Reconfiguring the Governance Structures of the Twenty-First-Century City-Region', International Planning Studies, 16(3), 201-215.

Jensen, M.D., Koop, C. and Tatham, M. (2014) 'Coping with Power Dispersion? Autonomy, Co-ordination and Control in Multilevel Systems', Journal of European Public Policy, 21(9), 1237-1254.

Jessop, B. (1990) State Theory: Putting the Capitalist State in Its Place. Cambridge: Polity Press.

Jimenez, B.S. (2014) 'Raise Taxes, Cut Services, or Lay Off Staff: Citizens in the Fiscal Retrenchment Process', Journal of Public Administration Research and Theory, 24(4), 923-953.

John, P. (2001) Local Governance in Western Europe. London: Sage.

Kersting, N. and Vetter, A. (eds) (2003) Reforming Local Government in Europe: Closing the Gap between Democracy and Efficiency. Opladen: Leske + Budrich. 
Klausen, K.K. and Magnier, A. (eds) (1998) The Anonymous Leader: Appointed CEOs in Western Local Government. Odense: Odense University Press.

Ladner, A. (2017) 'Autonomy and Austerity: Re-investing in Local Government', in C. Schwab, G. Bouckaert and S. Kuhlmann (eds), The Future of Local Government in Europe: Lessons from Research and Practice in 31 Countries. Baden-Baden: Nomos Verlagsgesellschaft, pp. 23-52.

Longo, E. and Mobilio, G. (2016) 'Territorial Government Reforms at the Time of Financial Crisis: The Dawn of Metropolitan Cities in Italy', Regional and Federal Studies, 26(4), 509-530.

Loughlin, J. (1996) “"Europe of the Regions” and the Federalization of Europe', Publius: The Journal of Federalism, 26(4), 141-162.

Loughlin, J. (2004) Subnational Democracy in the European Union. Oxford: Oxford University Press (with the collaboration of E. Aja, U. Bullmann, D.-L. Seiler and A. Lidström).

Loughlin, J. (2007) Subnational Government: The French Experience. Basingstoke: Palgrave Macmillan.

Loughlin, J. and Martin, S. (2005) 'Options for Reforming Local Government Funding to Increase Local Streams of Funding: International Comparisons', Final Draft Report, Prepared for the Lyons inquiry into Local Government Funding, accessed 14 February 2021 at http://orca.cf.ac.uk/id/eprint/50757.

Loughlin, J., Hendriks, F. and Lidström, A. (2010) 'Introduction: Subnational Democracy in Europe - Changing Backgrounds and Theoretical Models', in J. Loughlin, F. Hendriks and A. Lidström (eds), The Oxford Handbook of Local and Regional Democracy in Europe. Oxford: Oxford University Press, pp. 1-23.

Martin, L.L., Levey, R. and Cawley, J. (2012) 'The "New Normal” for Local Government', State and Local Government Review, 44(1), 17-28.

Monticelli, C. (2019) Reforming Global Economic Governance: An Unsettled Order. Abingdon: Routledge.

Mouritzen, P.-E. and Svara, J.A. (2002) Leadership at the Apex: Politicians and Administrators in Western Local Governments. Pittsburgh: University of Pittsburgh Press.

Neuman, M. and Hull, A. (2009) 'The Futures of the City Region', Regional Studies, 43(6), 777-787.

Norton, A. (1994) International Handbook of Local and Regional Government: A Comparative Analysis of Advanced Democracies. Cheltenham, UK and Northampton, MA, USA: Edward Elgar Publishing.

OECD (2017) Multi-Level Governance Reforms: Overview of OECD Country Experiences. Paris: Organisation for Economic Co-operation and Development.

Osborne, S.P. (2006) 'The New Public Governance?', Public Management Review, 8(3), 377-387.

Perlman, B.J. (2009) 'Fiscal Distress and Governance Challenges: The Perfect Storm of the Fiscal Crisis', State and Local Government Review, 41(3), 201-207.

Perlman, B.J. and Benton, J.E. (2012) 'Going It Alone: New Survey Data on Economic Recovery Strategies in Local Government', State and Local Government Review, 44(1), 5-16.

Piattoni, S. (2019) 'The Contribution of Regions to EU Democracy', in G. Abels and J. Battke (eds), Regional Governance in the EU: Regions and the Future of Europe. Cheltenham, UK and Northampton, MA, USA: Edward Elgar Publishing, pp. 16-32.

Pike, A., Rodríguez-Pose, A. and Tomaney, J. (2017) Local and Regional Development. London: Routledge. 
Rodríguez-Pose, A. (2008) 'The Rise of the "City-Region" Concept and its Development Policy Implications', European Planning Studies, 16(8), 1025-1046.

Rossi, U. (2017) Cities in Global Capitalism. Cambridge: Polity.

Sasken, S. (2001) The Global City. Princeton NJ: Princeton University Press, 2nd edition.

Schwab, C., Bouckaert, G. and Kuhlmann, S. (2017) 'Autonomy, Performance, Participation: Lessons from the Comparative Study of Local Public Sector Reforms', in C. Schwab, G. Bouckaert and S. Kuhlmann (eds), The Future of Local Government in Europe: Lessons from Research and Practice in 31 Countries. Baden-Baden: Nomos Verlagsgesellschaft, pp. 11-22.

Scott, A.J. (2001) 'Globalization and the Rise of City-Regions', European Planning Studies, 9(7), 813-826.

Steen, T., Teles, F. and Torsteinsen, H. (2017) 'Improving Local Service Delivery: Increasing Performance through Reforms', in C. Schwab, G. Bouckaert and S. Kuhlmann (eds), The Future of Local Government in Europe: Lessons from Research and Practice in 31 Countries. Baden-Baden: Nomos Verlagsgesellschaft, pp. 53-77.

Steiner, R., Kaiser, C. and Eythórsson, G.T. (2016) 'A Comparative Analysis of Amalgamation Reforms in Selected European Countries', in S. Kuhlmann and G. Bouckaert (eds), Local Public Sector Reforms in Times of Crisis: National Trajectories and International Comparisons. Basingstoke: Palgrave Macmillan, pp. 23-42.

Stiglitz, J. (2002) Globalization and Its Discontents. London: Penguin.

Ter-Minassian, T. and Fedelino, A. (2011) 'Impact of the Global Crisis on Sub-national Government's Finances', in Fiscal Policy: Lessons from the Crisis, Bank of Italy Workshops and Conferences no. 6, Rome: Italy, pp. 595-612.

Warleigh, A. (1997) 'A Committee of No Importance? Assessing the Relevance of the Committee of the Regions', Politics, 17(2), 101-107.

Watson, M. (2011) 'Global Trade and Finance', in J. Baylis, S. Smith and P. Owens (eds), The Globalization of World Politics. Oxford: Oxford University Press, pp. 444-457. 